\title{
A fás legelők és legelőerdők használata magyarországi pásztorok és gazdálkodók tudása alapján
}

\author{
Varga Anna ${ }^{1}$, Samu Zoltán Tamás ${ }^{2}$ és Molnár Zsolt ${ }^{1}$ \\ ${ }^{1}$ MTA Ökológiai Kutatóközpont, Ökológiai és Botanikai Intézet, \\ 2163 Vácrátót, Alkotmány u. 2-4. \\ ${ }^{2}$ Balatoni Múzeum, \\ 8630 Keszthely, Múzeum u. 2. \\ email: varga.anna@gmail.com
}

\begin{abstract}
Összefoglaló: A hagyományos ökológiai tudás a biológiai és kulturális örökség meghatározó eleme, mely számos élőhelytípus védelméhez elengedhetetlen információval szolgál. Ilyen élőhelyek például az agrár-erdészeti rendszerek közé tartozó fás legelők és legelőerdők, melyek iránt az utóbbi években a természetvédelem és az agrárium részéről is jelentősen megnőtt az érdeklődés. Célunk, hogy felvázoljuk az ezekre az élőhelyekre vonatkozó, ma is élő hagyományos ökológiai tudást. Kutatásunk során Magyarország 28 településén vagy azok határában 52 pásztorral és gazdálkodóval készítettünk interjút. Sok helyen a mai napig a hagyományos ökológiai tudáson alapul a fás legelőkön és legelőerdőkön történő legeltetés. A pásztorok és gazdálkodók az élővilágról, ökológiai folyamatokról és a legeltetésnek a legelök hosszú távú fenntartásában betöltött szerepéről is mély ismerettel rendelkeznek. Mindemellett kiemelendő, hogy bár egyre kevesebb, mégis számos - régi pásztorcsaládból való és újonnan lett - pásztor legeltet fás legelőkön is, akik a régiek tudását megbecsülik, fontosnak tartják a hagyományok továbbadását és a természet tiszteletét. A hagyományos ökológiai tudás alkalmazása a kiemelkedő természeti, valamint kulturális értékkel bíró gazdálkodás folytatása mellett hozzájárul a pásztorok szellemi kulturális örökségének és közösségének továbbéltetéséhez.
\end{abstract}

Kulcsszavak: hagyományos ökológiai tudás, agrár-erdészeti rendszerek, természetvédelmi kezelés, természetvédelmi őr, szellemi kulturális örökség, tájhasználat

\section{Bevezetés}

Az emberiség szellemi öröksége részét képező kulturális sokféleség elvesztésének fokozódó veszélye az elmúlt évtizedekben a természetvédelem egyik kiemelt kérdésévé vált az egész világon (Berkes 2008, Agnoletti \& Rotherham 2015, Schmeller \& Bridgewater 2016). Ennek az örökségnek meghatározó eleme a hagyományos ökológiai tudás, melynek természetvédelmi célú kutatása Magyarországon és a Kárpát-medence számos pontján az utóbbi évtizedben erősödött meg 
(Babai \& Molnár 2009, Molnár et al. 2009, Molnár 2011 ab, 2012, Molnár \& Molnár 2015, Kis et al. 2016). Az eddigi eredmények azt bizonyítják, hogy Magyarországon még ma is gazdag és élő a hagyományos ökológiai tudás, mely azonban a tájhasználat felhagyásával és az életmód átalakulásával eltünhet (Rotherham 2007, Biró et al. 2014). Számos olyan élőhelytípus van hazánkban is, melyek hatékony és hosszú távú megőrzéséhez az arra vonatkozó hagyományos ökológiai tudás nélkülözhetetlen (Csizi \& Molnár 2015, Szigetvári 2015). Az agrár-erdészeti rendszerek közé tartozó, kiemelkedő természeti és kulturális értékkel bíró fás legelők és legelőerdők egykori kialakulásának megértéséhez, jelenlegi használatához és jövőbeni fenntartásához egyaránt kulcsfontosságú a hagyományos ökológiai tudás megismerése és gyakorlati alkalmazása (Rackham 1998, Berkes et al. 2000, Drew \& Henne 2006, Varga et al. 2016, Schmeller \& Bridgewater 2016). A kisszámú, európai hagyományos ökológiai tudással foglalkozó tanulmány szinte kivétel nélkül megemlíti valamilyen formában a fás legelőket (pl. FernándezGiménez \& Estaque 2012, Johann et al. 2012, Oteros-Rozas et al. 2013). Ezek a munkák részben vagy teljesen, állattartással foglalkozó gazdák és pásztorok tudását ismertetik. Fás legelőkre vonatkozó információkat a legeltetéssel foglalkozó tanulmányok mellett (Redecker et al. 2002) a hagyományos erdő- és tájhasználatot ismertető munkákban találhatunk (Parotta et al. 2006, Gugić 2009). Az utóbbi években több tanulmány is megjelent az európai fás legelőkre vonatkozóan, melyek közül kiemelendő a Hartel \& Plieninger (2014) által szerkesztett, a témát legátfogóbban bemutató könyv és Hartel et al. (2015) tájtörténetet összefoglaló cikke. Mindkét tanulmány hangsúlyozza, hogy a fás legelők természeti és kulturális értékeit meghatározzák a mindenkori társadalmi viszonyok. A közép- és kelet-európai fás legelők természeti jellege és tájhasználata számos esetben mutat párhuzamot a magyarországi fás legelőkkel, mint például a tölgy- és vadgyümölcsfajok dominanciája (Hartel et al. 2013) és a gyepkezelés módszerei (Oellerer 2014). A magyarországi fás legelők és legelőerdők használatára vonatkozóan jellemzően az 1900-as évek első feléből származó erdészeti és mezőgazdasági írások (Varga \& Bölöni 2009, Halász et al. 2015) mellett az utóbbi években jelent meg több olyan írás, amely egy-egy terület tájtörténetét mutatja be (Saláta 2009, Geiger et al. 2011, Samu et al. 2015, Varga et al. 2015). Fás legelőkkel, legelőerdőkkel kapcsolatos néprajzi munkák jellemzően egy-egy táj vagy falu állattartási viszonyait vagy pásztorkultúráját mutatják be (Luby 1942, Petercsák 1983, Takács 1986, Eperjessy 2006, Andrásfalvy 2007). Többnyire azonban az erdősült tájak pásztorvilágának szellemi és kulturális örökségeként a népzenét és népmüvészetet emelik ki, míg a természetre és legeltetésre vonatkozó népi ismeretet (hagyományos ökológiai tudást) kevésbé hangsúlyozzák. 
Munkánk célja, hogy átfogó képet adjunk a magyarországi fás legelőkre és legelőerdőkre vonatkozó ma is élő hagyományos ökológiai tudásról. Reméljük, ez a rövid áttekintés elősegíti a fás legelők, legelőerdők természeti értékeinek hatékonyabb védelmét és a hagyományos ökológiai tudás szellemi örökségként való elismerését.

\section{Módszerek}

Magyarországon az idős, nagy és terebélyes fák által jellemzett fás legelők és legelőerdők kiterjedése Bölöni et al. (2008) adatai alapján kb. 5500 ha. Ez a kiterjedés csak a töredéke annak, ami egykor jellemezte az országot (Varga \& Bölöni 2009). Az elmúlt években az agrártámogatások és a külterjes állattartás iránti növekvő érdeklődés hatására számos egykori felhagyott fás legelőt és legelőerdőt kezdtek el újra használni, de még így is sok felhagyott terület van az országban (Varga et al. 2015). Kutatásunk célja a fás legelőket egykor és ma használó pásztorok és gazdálkodók ide vonatkozó hagyományos ökológiai tudásának feltárása.

A kutatás során olyan egykori és jelenleg aktív, legeltető állattartással foglalkozó gazdálkodókat és pásztorokat kerestünk fel, akik valamilyen formában részt vettek vagy napjainkban is részt vesznek a fás legelők és legelőerdők használatában és kezelésében. Az interjúalanyok kiválasztása során első lépésként célzottan kerestünk fel általunk ismert és a témában érintett pásztorokat és gazdálkodókat. Ahol nem ismertünk senkit, ott a helyi természetvédelmi őrt, illetve a helyi ismerősöket kértük meg, hogy mutassanak be minket a helyi fás legelön egykor vagy ma is legeltető pásztornak. Előfordult, hogy az adott fás legelőn spontán találkoztunk a helyi pásztorral. Ezek után a hólabda módszert alkalmazva kerestünk fel további adatközlőket. Az egyik szerző maga is fás legelő-tulajdonos és állattenyésztéssel részben foglalkozó gazdálkodó, aki magához a kutatásokhoz is szolgáltatott adatokat, illetve az adatok helyes értelmezéséhez a bennfentes szakértelmével járult hozzá. A megkérdezett interjúalanyok által ismert fás legelők az 1950-es évek előtt jellemzően közösségi, egy-két esetben földesúri legelőterületek voltak, ahol a falu vagy a legelőtulajdonos csordája, kondája, nyája legelt. Ebben az időszakban a községi területeken legeltetési társulatok fogták össze a legeltetést. Az 1950-es és 1990-es évek között az összes terület tsz-tulajdonban és -irányítás alatt volt, az 1990-es évek után többségében magánkézbe kerültek, melyek közül sok osztatlan közös tulajdonú lett. Az osztatlan közös területeket többnyire felhagyták, vagy magángazdálkodó kezdte el legeltetéssel vagy kaszálással hasznosítani. Újbóli haszonvételük 2010 környékén indult meg. A védett fás legelők közül több állami tulajdonban és nemzeti park igazgatósági vagyon- 
kezelésben van. A fás legelök területe a 10-20 hektárostól a több száz hektárosig terjed (Varga et al. 2017). Az 1970-es évekig elsősorban szarvasmarha és sertés legeltetése volt jellemző, de szórványosan a juh is előfordult. Az 1970-es évek után a sertés külterjes legeltetése megszünt, jellemzővé vált a szarvasmarha istállózása, előtérbe került a juhlegeltetés (Varga et al. 2016). Összesen 52 emberrel (17 gazdálkodó, 35 pásztor, életkoruk 28 és 91 között volt, átlagos életkor 54 év) készítettünk félig strukturált interjúkat Magyarország 28 településén vagy annak határában. Az interjúk hosszúsága eltérő volt, a többsége kb. 1.5-2 órát vett igénybe, de volt, amelyik akár 3-4 órát vagy akár fél napos beszélgetéseket is jelentett. Az interjúk során a fás legelők jelentését, használatát, élővilágát, értékeit és fenntartásának előnyeit, nehézségeit, a fenntartáshoz szükséges tudás megszerzésének módjait, témakörét jártuk körbe az interjúalanyokkal. A beszélgetések az 1930-as évektől napjainkig tartó időszakra vonatkoztak. Ahol volt lehetőség, ott részvételi adatgyüjtést (összesen 60 nap) is végeztünk, melynek során a legeltetésbe, illetve a fás legelök kezelésébe megfigyelőként vagy akár aktívan is bekapcsolódtunk. Az interjúkat az interjúalanyok hozzájárulásával, diktafonnal rögzítettük, majd azokat legépeltük. A részvételi adatgyüjtések során írott jegyzeteket és fényképfelvételeket készítettünk. Az interjúk szövegeit és a terepi jegyzeteket kvalitatívan elemeztük, s az eredmény fejezetben bemutatott nyolc témakör szerint kódoltuk (Babbie 2008). Az idézetek végén zárójelben az interjú készítésének helyszínét, illetve az interjúalany nevének monogramját tüntettük fel.

Kutatásunkat 2010 és 2016 között a magyarországi fás legelőket reprezentáló tájakban: a Bakonyban, a Balaton-felvidéken, Belső-Somogyban, a Beregi-síkon, a Bükkben, a Duna-Tisza közén és a Sárközben végeztük, az alábbi településeken és határukban található legelőkön: Bakonyszentkirály, Bogyiszló, Cserépfalu, Csesznek, Csokonyavisonta, Dörgicse, Drávaszentes, Gelénes, Homokszentgyörgy, Kunbaracs, Lovas, Lónya, Marcali, Márokpapi, Nagyesztergár, Nyirád, Olaszfalu, Pénzesgyőr, Pusztakovácsi, Sáska, Soltszentimre, Somogyfajsz, Somogysárd, Somogyvár, Szentgál, Szulok, Tótvázsony, Vámosatya.

Az itt bemutatott adatokat részben közöltük már angol nyelven (Varga \& Molnár 2014, Molnár et al. 2016, Varga et al. 2017).

\section{Eredmények}

A fás legelök és a pásztorközösségek változása és jelenlegi helyzete

A fás legelők kiterjedése, jellege és használati rendje is nagymértékü változásokon esett át az elmúlt 200 évben. Az egyik legjelentősebb változást az iparosodás és a hagyományos közösségi tájhasználat fokozatos visszaszorulása idézte elö. 
„1959-ben alakult a tsz, azóta nincs pucolva, azóta vége. Semmit. Semmit. Nem is lett semmi. Most vaddisznó tanya." (Olaszfalu, N.A.) A jelenleg használatban lévő fás legelök többnyire magán- vagy állami tulajdonban és ez utóbbi esetben nemzeti park igazgatósági vagyonkezelésben vannak. A fás legelőkön legeltető gazdák többnyire bérlik a területeket. 2004 után több helyen, föként agrár-környezetgazdálkodási (AKG) programmal érintett és Natura 2000-es területeken indult meg a cserjék irtása, a kaszálás és a legeltetés. A visszaalakítási munkálatok során a gazdák és a pásztorok sérelmezik, hogy a legelőn nem lehet égetni, tüzelni. A cserjeirtás az esetek többségében ma már szárzúzóval történik, ami sok helyen a teljes fásszárú újulat letarolásával jár. A hagyományos és tudatos, legeltető fás legelö-használatot egyre inkább felváltja a villanykarámmal történő legeltetés. A hagyományos ökológiai tudás használata visszaszorul. A pásztor nélküli jószág a legelö növényzetét máshogy, többnyire túlhasználja.

A hagyományos falusi társadalom felbomlása egyet jelentett az állattartó közösségek megszünésével. Az állattartó gazdák és a pásztorok is hiányolják azt a fajta közösségi életmódot, melyben lehetőség nyílt folyamatos kapcsolattartásra. „Nem lehetünk pásztorok. Abban az idöben, ha összejöttünk, egy-két pásztorember kint a legelön, cseréltünk. Csengöt, kolompot, botot, kutyát. Már nincsen senkinek sem." (Sáska, K.J.) A hagyományos állattartás megmaradásának legnagyobb akadályát az egyre sokasodó bürokratikus feladatokban, a túlzott szabályozásban és az emberek elkényelmesedésében látják. „Nem ér rá a fiam a birkák közé állni. Most is Veszprémbe’ kell a papírokat intéznie." (Dörgicse, B.I.) A bakonyi és Balaton-felvidéki fás legelökön legeltető pásztorok több mint 10 éve évente többször szerveznek pásztortalálkozókat, melynek egyik célja a pásztorközösség megerősítése és összefogása (1. ábra).

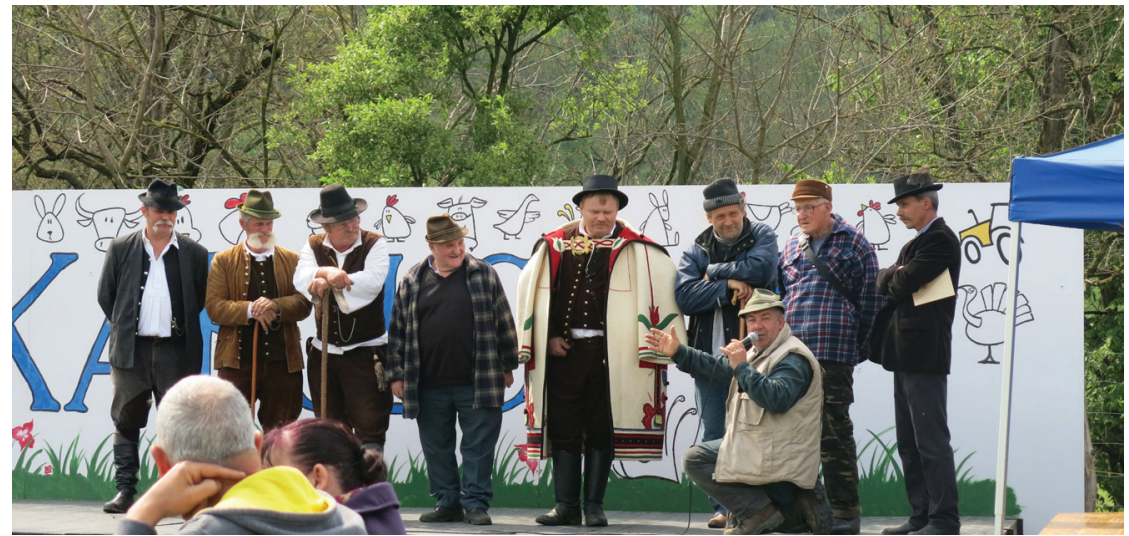

1. ábra. A Balatoni-Bakonyi pásztortalákozót már több mint 10 éve rendszeresen megszervezik a helyi pásztorokkal és állattartó gazdálkodókkal együttmüködve. A kép 2016-os találkozón készült, Kapolcson. fotó: Varga Anna 
Természet és ember viszonya

A pásztorok elmondásai alapján a fás legelők, legelőerdők és általában a természeti erőforrások fenntartható használatához a természet alapos ismerete szükséges. A legeltetés során többnyire egyszemélyes döntéseket kell hozni, ezért rendkívül fontos, hogy milyen tudással és szemlélettel bír az adott pásztor vagy gazda. A pásztorok, gazdák maguk közül a legjobbaknak az odafigyelő, felelősségteljes és az ,állatok nyelvén is értőket” tartják. Azok a gazdálkodók és pásztorok, akik nem kizárólagosan gazdasági érdekből foglalkoznak állattartással, a régiek tudását megbecsülik. Fontosnak tartják a hagyományok továbbadását, a jószág szeretetét, az ősök és a természet tiszteletét. Mindezek gyakorlati megnyilvánulása tájanként és koronként is különbözhet, de az alapelvek változatlanok.

„A jószág fejével próbálunk gondolkodni, ugyanúgy, ahogy egy észak amerikai indián. Hiába a világ másik végén lakunk, mert ö is a jószág fejével gondolkodik, meg én is azzal próbálok. Pontosan a jószág fejével kell gondolkodni, akkor tud vele együtt élni az ember! Csak úgy müködik, sehogy máshogy. Aki ezt nem fogadja el, az nem fog boldogulni a természetbe’. Az elöbb utóbb feladja, és menekül vissza, valahová, Isten tudja hová [az adatközlö juhász a nyájára mutat, a 130 fej a 130 jószágot jelenti a nyájában]. Hogy tudsz 130 fejet irányítani? Önállóan gondolkodó fejet, ha megelözöd mindnek a gondolkodását, csak úgy. Mert meg kell elözni, tudnod kell elötte, hogy mire gondol, mielött ö már gondolná, és 130 önálló gondolkodás mind. Mert gondolkodik akárhogy. Itt ahány darab, itt mindenki gondolkodik. Itt nincs két egyforma, se külsöre, se belsöleg.” (...) „Meg kell tanulnunk együtt élni a természettel. De ahhoz nagyon sok idöt el kell tölteni, hogy az ember rájöjjön dolgokra. Vagy magától vagy mástól, ki milyen inditást kap otthonról és másoktól. S kinek milyenek a gyökerei, mert az számít, az a legmérvadóbb, az indulás.”(...) „Az a fájó az egészbe’, hogy itt már minden olyan emberek kezébe kerül, akik pénz miatt tartanak állatot. Ha én csak pénz miatt tartanék állatot, akkor már réges régen nem lenne. De hát érzelmi alapon müködik majdnem minden, de lehet, azért müködik, mert az érzelem is benne van." (Szulok, B. K.)

\section{A legelön lévö fákról}

A fás legelő hagyományosan egy komplex, agrár-erdészeti rendszer részét képezi, ahol a lehetőségekhez mérten a pásztor ,körbelegeltette a határt” időjárástól és napszaktól függően. Az erdősült vidékeken a fás legelö legtöbb esetben egyet jelent a legelővel, és a nyílt gyepen keresztül a teljesen zárt erdőig különböző lombkorona-borítású részek is részét képezik a legelőnek. A legelőn lévő fák meghagyása elsősorban gyakorlati okokból történik. „Jó tölgyfák vannak az iga- 
zi legelön. Az az igazi legelö, amin a birka elmehet az egyik hüsröl a másikra." (Dörgicse, B. I.) (2. ábra).

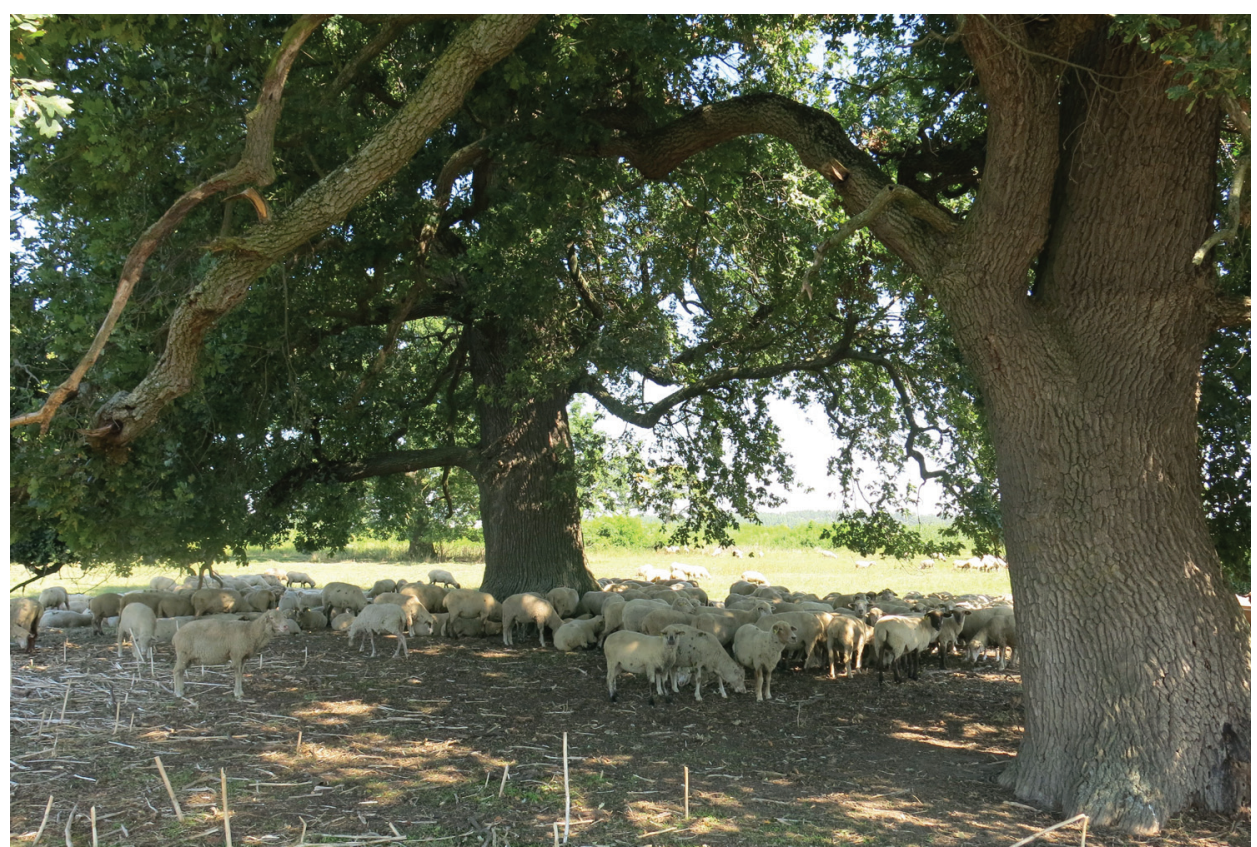

2. ábra. Hüsölő birkák a terebélyes kocsányos tölgyek alatt Bogyiszló (Tolna megye) község határában fekvő Kasztói őstölgyes fás legelőn. fotó: Varga Anna, 2016

A legelő fái alatt szélsőséges időjárás esetén védelmet talál a jószág és a legeltetést végző ember is. Ez különösen fontos a déli órákban és a nyári nagy melegekben. „Legelön voltak fák. De csak úgy hogy $100 \mathrm{~m}^{2}$-re esett egy, esetleg kettö. Meghagyták hüsölönek, hogy a felmelegedett idöben a jószágnak hüvöst adjon. A pásztornak is jó volt. Amerre legeltek, ha hüvösön feküdtek, látta a nyájat." (Homokszentgyörgy, B. K.)

Kiemelik a fák gyepre való mikroklimatikus hatását, mely elsősorban a kora tavaszi időszakban és a nyári, nyárvégi szárazságok idején játszik szerepet. „,Kicsit másabb a gyep, mert hüvösben van. Mindig egy kicsit szelídebb. Ahogy a juh bemegy alá, kitapossa, tavasszal mindig frissebb a fü." (Vámosatya, B.I.)

Mindezek mellett a késő nyári és kora őszi időszakban a fák termése a takarmányozásban játszik fontos szerepet (Varga \& Molnár 2013, Varga et al. 2015). Elsősorban a disznók, de a juhok és egyes esetekben a szarvasmarhák is előszeretettel fogyasztják a makkot. A vadgyümölcsök (pl. vadkörte, vadalma) termését nemcsak a jószágok eszik szívesen, hanem emberi felhasználásra is gyüjtik (pl. aszalás, pálinka). A legelőn növő fákat számon tartják, és szinte egyenként isme- 
rik a pásztorok és a jószágok is. „A disznókat alig lehetett megfogni a vadkörtére, egy kilométert képes volt elfutni, tudta, hogy hol van vadkörte. Somhegy-lapon is volt két fa, nagyon finom vadkörte volt rajta. Ha véletlenül összel, elkezdett potyogni, mikor finom édes volt, akkor ha mink akartunk enni belöle, elöl köllött futnunk, hogy együnk a disznók elött körtét." (Olaszfalu, N. A.)

A fákban történő „károkozás” mértékét nagyban meghatározza a pásztor odafigyelése és a jószág jelleme is. Az állatok leginkább a kora tavaszi időszakban szeretik csipegetni a zsenge és nem túl keserü leveleket. „Úgy tudtak [a legelőn a fák] fölnöni, hogy körbe volt bokorral, hogy ne tudjon a birka odamenni. A körisfát fölnyúzzák a kecskék, meg a birkák is. De a cserfát nem. Meg pucolgatni kell. Régen összejöttek a falubeli emberek, aztán kitakaritották [azokat a fásszárú növényeket, amikre nem volt szükség és a legelö elcserjésedését okozták volna] öket. De máma már ilyen nincsen. Traktorral kell pucolni, meg géppel. De én nem azzal szokom, így megmaradnak a fáim. Van olyan körtefám, amit valamikor bicskával pucolgattam föl, ma ilyen törzse van. Az jó, azt szereti a birka, hogy ha hullik a vadkörte. Pálinka is jó van belőle.’(Sáska, K. J.)

A gyep-, cserje- és lombkoronaszint használata és tudatos, finom léptékü kezelése

A legelőn felnövő fák meghagyását befolyásolja, hogy milyen termést hoznak, milyen az árnyékadó képességük, és milyenek a fiatal egyedek adottságai (pl. mennyire sudárak, egyenesek). A kiválasztott csemetéket számon tartják, és figyelnek rá a legeltetés során. „Ahogy, tetszés szerint. Egyenes, nem görbe, a girbegörbét nem hagyták meg. Törzse legyen, teteje, sugara. ”(Olaszfalu, N.A.) / „Ha jó növekedésünek, jó állásúnak indult, akkor itt ért ez a fa, had nöjön fel. Akkor már vigyázott rá a pásztor, és érdekes volt, hogy a kutya úgy megszokta, hogy ha olyan fához ment valamelyik jószág. Elöadódott, hogy neki dörgölözött, kétfelé is tört. A kutyának csak azt kellett mondani, hogy „Sssztt te”, akkor már tudta, hova kell menni. Ment a nagyjószágnak, az orrát csípte. Karmolta kifele. Ott hagyta a fát, mert a kutya nem hagyott neki nyugtot. Érdekes jelenség volt. Úgy betanult a kutya." (Sáska, K. J.)

Magyarországon a lombtakarmány gyüjtésére többnyire csak az aszályos években került sor, ez ma már szinte csak az emlékekben él. Ehhez hasonlóan az egykor elterjedt botolásra - eltekintve a füzfák esetétől - már nem találtunk élő gyakorlati példát. A fák használatához és kezeléséhez hozzá tartozik két, főként tavasszal végzett tevékenység: a fák megcsapolása, fanedv (pl. nyír) nyerésének céljából, illetve a farajzok (pl. bükk) készítése. A legelőn lévő idős fákat tisztelet övezi. A fa kivágásának a joga mindig a terület tulajdonosát illette. A korhadt, kiszáradt fákat többnyire eltávolíttatják a legelőről, mivel a váratlanul letörő ágak, 
vagy magának a fának kidőlése veszélyezteti a legelő jószágot és a pásztort. „Öreg fákat nem volt szabad bántani, amiket elszáradtak azokat esetleg. Már kéreg nem volt rajtuk, de azokat valakinek odaadták. Meg nem nagyon kapaszkodtak érte, mert rettenetes megmunkálni. Nagyon nehéz 300 éves tölgyfákat, 2-300 éves fákat, annyira göcsörtösek. Azokat nem volt szabad bántani." (Homokszentgyörgy, B.K.) / „Fát, hogyha az megint csak a Legeltetési Társaság közösségé [20. század első fele, jelenleg is a terület tulajdonosa - ma már többnyire magánszemély dönt a korhadó, beteg fák kivágásáról] volt, évente csináltak árverést, és a beteg fákat megjelölték, ha túl sürün nöttek, azokat kivágták, és a befolyt pénz a gazdaközönség bevétele volt. Nem kellett ültetni, mert megvolt a természetes utánpótlás. Nem tudok róla, hogy ültetni kellett volna, hogyha olyan fa volt, amit érdemes volt meghagyni, azt még védték is. (...) Általában ott hagyták meg, ahol bokor volt, bozótos részen hagyták meg, úgy megerösödött, hogy a vadállatok nem árthattak neki, akkor kivágták a bozótot. Ez volt a megszokott, meg általában ott is kelt ki a bozótban, mert az állat nem fért hozzája." (Olaszfalu, N. A.)

A fák törzsének illegális kiégetésére is jegyeztünk le példát, ez többnyire lódarazsak vagy méhek kiüzése céljából történik. A cserjeszintet is tudatosan kezelik, visszaszorítják a terjedését. Az éves nagy legelőtisztítás mellett, a pásztor feladata legeltetés közben a szúrós növények alkalomszerü eltávolítása a legelőről. „Mikor apámmal a disznókat őriztük, egy kis kapa szokott nálunk lenni. Ö nála, meg én nálam is, hogy ezt a mácsonyatüskét, amerre mentünk, kiforditottuk a kapával, nem engedtük fölnőni." (Bakonyszentkirály, M.E.) A fiatal újulat védelme érdekében cserjéket hagytak meg. A cserjeszint bokrainak nagyon finom léptékü és több éven keresztüli egyedi kezelését jelenti a pásztorbotkészítés. Pásztorbotnak a legalkalmasabb a som, de kökényt és vadkörtét is használnak erre a célra. ,Pásztorbotnak valót ott gyüjtök, ahová megyek. A Mecsekbe, itt helyben. Itt vannak a kifütésre való somfabotjaim [pásztor a pásztorbotjait megmutatja, a pásztorbot elkészítésének egyik lépése a „kifütés”, vagyis a bot kiegyenesítése céljából való felhevítés]. Zalából, ahol éppen járok és találok. Egy van kifütve, egy báránykampóra való, ez is somfa. Ezt még füteni kell és egyenesíteni. Ezt magam neveltem, és magam cirádáztam, és úgy nött ez föl. Ez körtefa, vadkörte. Ezt 2 évig egyengettem, már csak ki kell füteni. Be kell vagdosni, és ezek a forradások rajta maradnak végig. Ez meg lesz fütve, és le lesz pucolva, akkor egész mást fog mutatni." (Homokszentgyörgy, B. K)

A legelő fühozamának gyarapítása, ezáltal a takarmány növelése mindig fontos cél volt. Ennek érdekében a gyepszintet égetik alacsony, perzselésszerü tüzzel, annak ellenére, hogy a tűzgyújtás a tiltott tevékenységek közé tartozott. „Fel is égették tavasszal a legelöt. Sokkal szelídebb volt, ha az avar elégett, csak azóta nem engedik.” (Olaszfalu, N.A.) „Hát azelött [1950-es évek előtt, pontos időpont nem 
áll rendelkezésre], mikor már száraz idö volt tavasszal, kihajtás elött. Megnézték a széljárást, és úgy gyújtották be, meg vigyáztak, hogy egyéb tüzet ne okozzanak. Akkor felfrissült minden, azok jobb legelök voltak. Minden új lett. Ha minden évben nem is, de voltak ilyenek." (Dörgicse, B. I.)

\section{A legeltetés rendje}

A legeltetés napirendje alapvetően a legeltetést közvetlenül végző pásztortól függ, aki a jószág igényeit figyelembe véve igazodik az időjáráshoz, a legeltetésre rendelkezésre álló terület viszonyaihoz és saját maga lehetőségeihez. „Nyáron például reggel jövök, 6 óra, fél 6. Akkor szoktam jönni. Elöször a bárány választás, utána kiengedem. Legeltettem. 9-fél 10 felé itatás, majd deleltetés, mert a pöcsik összehajtja. 5 óráig déleltettem, este fél 9-ig legeltettem." (Vámosatya, B.I.) Az éves legeltetési rendet nagymértékben befolyásolja a terület tulajdonosa és az éppen aktuális jogszabályi környezetben megfogalmazott elöírások. Vannak olyanok, akik a jószág jó tartása végett kockázatot is bevállalnak, és tiltott területen legeltetnek, például erdőben.

Az államosítások előtti időszakban a legelők használatát többnyire a faluközösségek írott és íratlan törvényei szabályozták. Az 1950-es évek után a nagyüzemi jelleg kialakulása mellett, a tudatos legelőhasználat fokozatos elmaradása figyelhető meg. Jelenleg a legeltetési rendet nagymértékben meghatározza a terület természetvédelmi besorolása, az AKG-s és Natura 2000-es elöírások. Rendszerint a kora tavaszi hónapok során történt a legelők tisztítása, amelyet többnyire még 2030 éve is kézi szerszámokkal és tüz segítségével végeztek. Ma már ezek a munkák gépekkel és jellemzően a késő őszi-téli hónapokban történnek. Magyarországon a legelőkön való legeltetés Szent György-nap után, április végén-májusban indul meg az időjárástól függően (a juhokkal akár egy hónappal korábban). A legelőkön folyó legeltetést a nyár végi hónapoktól kezdődően egészen tavaszig a lekaszált rétekre, learatott szántóföldekre és az erdőbe való hajtással egészítették ki. Ma már ezeken, az úgynevezett „kiegészítő vagy nem konvencionális legelőterületeken" folyó legeltetés jelentős akadályokba ütközik (az erdőben való legeltetés tilos, és a tarlólegeltetés is számottevően visszaszorult, mivel aratás után pár nappal a gazdák már elkezdik a tarlóhántást a gyomosodást megelőzve, vagy vegyszeres gyomirtást alkalmaznak). „Hát, mire a makkozás megindult, a gulyások ki szoktak menni a kaszálórétekre legeltetni. Akkora már sarjúszéna is bekerült a laposabb kaszálórétekröl és, ott 3 hét alatt megnött újra a fü, hogy a marha is jó lakott. A tölgyes legelöböl addigra kikopott már a fü, és mentek a kaszálóréteket legeltették. Onnét teleltek be." (Nagyesztergár, M.J.). A fás legelőn a legeltetés tájtól, éghajlattól és állatfajtól függően október, esetleg november végéig (Szent Mihály- és Szent András-nap) tartott. Jellemző volt, hogy az első nagyobb dérig vagy 
hóig kihajtottak. A fás legelökön szarvasmarha, sertés, juh, ló, kecske és bivaly, elvétve szamár legeltetése is folyt. A disznókat és a marhákat a legelö különböző részein legeltették. Ma már többnyire juhot és marhát legeltetnek, egy-egy helyen előfordul a kecske és ló legeltetés. Bivallyal egyre több helyen lehet találkozni. A disznók külterjes, terelő legeltetése megszünt.

Az élövilág ismerete

A legelőn előforduló állatfajok közül legtöbbször a madarakat (seregély, búbos pacsirta), illetve az emlősfajokat (őz, vaddisznó) említik. A rovarok közül a méhek, lódarazsak és a legyek előfordulását szokták kiemelni. A növényfajok közül elsősorban az adott legelöre jellemző gyakoribb füfajokat, illetve fásszárúakat tartják számon. A legelőn előforduló gombafajokat is ismerik és gyüjtik. Nyomon követik a legelő élővilágának, főként a kiemelt funkcióval bíró fajok populáció-változásait, de a ritkább és különlegesebb fajokra is felfigyelnek. „Olyan madarakat látok, amik itt nem igen voltak elterjedve. Galamb méretü madár Ukrajnából jön errefelé. Vörösszárnyú feketerigó [fenyőrigó] itt-ott felbukkan a madár, föleg a tölgyes szélen. Figyelünk mi is a természetre! Elveszik itt bogár, meg madár, kiveszik. S ezzel a száraz éghajlattal, ahogy jön a szárazság, itt most át fog alakulni. Meg fognak jelenni olyan állatok, amik nem voltak, el fognak tünni olyan állatok, amik voltak, majdnem törvényszerü. Megváltoznak a körülményei az állatoknak."(Szulok, B.K.)

A növényzet változásának követése alapvető a legeltetés szempontjából. A legeltetés alapját a gyep adja, ezért a cserjésedést különösen veszélyes tényezőnek tartják, melynek során elsőként a kökény, a vadrózsa és a galagonya kezd terjedni. Megfigyeléseik szerint a legelőhasználat felhagyása után, a terület jellegétől függően, az erdős tájakban a zárt cserjés átlagosan 5-10 év alatt, zárt erdő 15-30 év alatt tud kialakulni. A legelők becserjésedésének okát az állatállomány csökkenése mellett leginkább a rendszeres tavaszi és legeltetés közbeni spontán tisztítási munkák elmaradásában látják a pásztorok és a gazdálkodók.

\section{Tudásátadás}

A pásztorközösségek hagyományos tudásátadó funkcióval bíró "bojtár - számadó pásztor" rendszere szinte teljesen megszünt az országban. Ennek során a munkába való bevonással tanították az idősebb pásztorok a fiatalabb generációt gyermekkortól kezdődően. A gazdák, hasonlóan a pásztorokhoz, szüleik, nagyszüleik mellett felnövekedve tanultak bele a gazdálkodásba. A pásztorkodás nem csupán egy foglalkozás, hanem egy életforma, mely speciális szemléletet kíván. Talán manapság ezért is figyelhető meg egyfajta érdektelenség a fiatalok körében. „Ott kell élni, benne kell lenni, nyitott füllel, nyitott szemmel, és nagyon nagy alázatot 
kíván, mert nem a jószág alkalmazkodik az emberhez, hanem az ember a jószághoz." (Vámosatya, B.I.). Ugyanakkor még mindig lehet találkozni olyan 20-30 év körüli pásztorokkal és gazdákkal, akik tudatában vannak öseik örökségének, alkalmazzák azt munkájuk során, és gyermekeiknek is tovább kívánják adni.

\section{Együttmüködés a hivatásos természetvédelemmel}

A jelenleg is használt nagy, idős fák jellemezte fás legelök többsége védett vagy Natura 2000-es terület, ezért valamilyen formájú kapcsolat mindenképpen kialakul a legeltető pásztor/gazdálkodó és a természetvédelem között. Azok a pásztorok, akik hosszú ideje legeltetnek ugyanazon a területen, vagy ők maguk a legelötulajdonosok, általában személyes kapcsolatban állnak a helyi természetvédelmi őrökkel. Sok esetben a tapasztalt együttmüködés egyik hatása, hogy a természetvédelem számára kiemelt fajokat egy idő után a pásztorok is számontartják és figyelik. A helyi őrrel való személyes viszonytól függően rendszeres adatokkal (monitoring munka) is szolgálnak. „Zolival /helyi természetvédelmi ör] '91 vagy '92-ben ismerkedtem meg, amikor a háromfai határban legeltettem. Egyszer csak beállitottak hozzám. Akkor létezett ott még ürge, és ott beszélgettem vele. Akkor még nyírogattam, még nem volt brigádom, egyedül járogattam nyírni. Akkor vett a Duna-Dráva Nemzeti Park rackákat, huszon pár darabot nyírtam meg nekik. A fekete gólyáról nem tudtak, ami itt van, én szóltam a Sanyinak, sőt nem is én, hanem Csaba, az emberem, hogy ott a fekete gólya. A másik fekete gólya fészek, arról tudott, én nem tudtam." (Szulok, B.K.) A hagyományos értékrenddel bíró pásztorral, gazdával való kapcsolat a természetvédelmi kezelést végző természetvédelmi őr tudását és mentalitását is tudja formálni, pl. a hagyományos legeltető állattartás és természetvédelem tudatos és gyakorlati összekapcsolása kapcsán (Varga et al. 2017).

\section{Értékelés}

A pásztorok a mai napig kiemelten fontos szerepet játszanak nemcsak a fás legelők és legelőerdők fenntartásában, hanem a hagyományos ökológiai tudás és az ehhez kapcsolódó életmód megőrzésében és továbbadásában is az egész világon. Nincs ez másként Magyarországon sem (Kis et al. 2016). A közelmúltban, illetve még napjainkban is fás legelőkön legeltetö pásztorok természeti erőforrások használatán közvetlenül alapuló életmódja, tudása, világszemlélete, hitvilága a mai napig kiemelkedően sok hagyományos elemet őrzött meg. Erre mutat rá többek közt Roturier \& Roué (2009), Roturier (2011) rénszarvaspásztorok közt, Fernández-Giménez \& Estaque (2012) pireneusi téli-nyári legelőváltó 
(transzhumáló) pásztorok között végzett kutatása és Molnár (2012) kutatása is. Molnár (2012) megállapította, hogy a hortobágyi pásztorok növényismerete akár 90\%-ban is független lehet a tudományos tudástól. Hasonlóan gazdag és adaptív ismerettel rendelkeznek azok a gazdák, akik hagyományos tájhasználati rendszereket tartanak fent, pl. a Gyimesben (Babai 2014) és a francia Alpokban (Meilleur 2010). A magyarországi fás legelőkhöz és legelőerdőkhöz hasonlóan a fentebb említett területeken is a társadalmi és természeti körülményekhez folyamatosan alkalmazkodó tájhasználatot folytatnak a pásztorok és gazdálkodók, melynek célja az erőforrások hosszú távú fenntartása (Glasenapp \& Thornton 2011). Fontos megemlíteni, hogy az utóbbi években a pásztorok és gazdálkodók mellett a természetvédelmi szakemberek is egyre gyakrabban foglalkoznak a fás legelök kezelésével Európa-szerte (Stiven 2006, Harmos 2013). A felmerülő kérdések és gyakorlati problémák megválaszolására a konkrét kezelést végző természetvédelmi őr egyre többször tudatosan egyeztet a legeltetést végző pásztorokkal, illetve maga is alkalmazza a hagyományos ökológiai tudást a természetvédelmi kezelések kapcsán (Molnár et al. 2016, Varga et al. 2017). A gazdálkodók és pásztorok, mint érintettek, bevonása a közösségi tudás gazdagítása mellett a hatékony természetvédelem megerősítéséhez is hozzájárul (Mihók et al. 2016). Mindezek felhívják a figyelmet arra, hogy a természetvédelemnek kiemelten fontos szerepe van a természeti értékekkel szorosan összekapcsolódó szellemi kulturális örökség és ennek részeként a hagyományos ökológiai tudás megőrzésében és továbbadásában (Csonka-Takács 2010, Rotherham 2015, Celentano \& Rousseau 2016, Kis et al. 2016). Ennek elősegítésének egyik lehetősége lehetne a magyarországi pásztorok hagyományos ökológiai tudásának UNESCO Szellemi Kulturális Örökség jegyzékébe való felvétele (Csere 2013).

Köszönetnyilvánitás - Köszönettel tartozunk mindazon pásztoroknak, gazdálkodóknak és természetvédelmi szakembereknek, akik segítették munkánkat és megosztották velünk tudásukat, kiemelten: Bende István, Béres Sándor, Borbély Demeter, Bödő Károly, Dávid László, Ebesfalvi Sarolta, Frecot Emese, Habarics Béla, Horváth Zoltán, Juhász Imre, Konkoly József, Kulcsár Péter, Lancz Kálmán, Márffy Bence, Máté András, Mészáros András, Molnár Elek, Molnár József, Nagy Tibor, Németh Antal, Némethné Hajas Mária, Nyemcsók Tamás, Omacht Zoltán, Orbán Kálmán, Paládi Vince, Polgár Emil, Polgárné Molnár Ilona, Simon Pál, Sinka Gábor, Sümegi József, Szücs Gábor Tamás Károlyné Kiss-Tóth Vilma, Tózer Ferenc, Vadász Csaba. Köszönjük Haász Gabriella és Végh Borbála nyelvi lektorálását és a két szakmai lektornak a hasznos és alapos bírálatot. 


\section{Irodalomjegyzék}

Agnoletti, M. \& Rotherham, I. D. (2015): Landscape and biocultural diversity. - Biodivers. Conserv. 24: 3155-3165. doi: http://dx.doi.org/10.1007/s10531-015-1003-8

Andrásfalvy, B. (2007): A Duna mente népének ártéri gazdálkodása. - Ekvilibrium Kiadó, 438 p.

Babai, D. \& Molnár Zs. (2009): Népi növényzetismeret Gyimesben II.: termöhely- és élőhelyismeret. - Botanikai Közlem. 96: 145-173.

Babai, D. (2014): „Azt nem lehet elmondani, mennyi szép színű virág van, egyik szebb a másiknál...” - Ethno-Lore: A Magyar Tudományos Akadémia Néprajzi Kutatóintézetének évkönyve 31: 339378.

Babbie, E (2008): A társadalomtudományi kutatás gyakorlata. - Balassi Kiadó, Budapest, 788 p.

Berkes, F. (2008): Sacred Ecology. - Routledge, London and New York, 313 p.

Berkes, F., Colding, J. \& Folke, C. (2000): Rediscovery of traditional ecological knowledge as adaptive management. - Ecol. Appl. 10: 1251-1262. doi: http://dx.doi.org/10.1890/10510761(2000)010[1251:ROTEKA]2.0.CO;2

Biró, É., Babai, D., Bódis, J. \& Molnár, Zs. (2014): Lack of knowledge or loss of knowledge? Traditional ecological knowledge of population dynamics of threatened plant species in East-Central Europe. -.J. Nat. Conserv. 22: 318-325. doi: http://doi.org/10.1016/j.jnc.2014.02.006

Bölöni, J., Molnár, Zs., Biró, M. \& Horváth, F. (2008): Distribution of the (semi-) natural habitats in Hungary II. Woodlands and shrublands. - Acta Bot. Hung. 50: 107-148. doi: http://doi. org/10.1556/ABot.50.2008.Suppl.6

Celentano, D. \& Rousseau, C. A. G. (2016): Integral Ecological Restoration: Restoring the Link between Human Culture and Nature. - Ecological Restoration 34: 94-97. doi: http://doi. org/10.3368/er.34.2.94

Csere, L. (szerk.) (2013): Hagyományos halászat a Duna magyarországi alsó szakaszán. Jelölés a Szellemi Kulturális Örökség Nemzeti Jegyzékére. - Szabadtéri Néprajzi Múzeum, Szellemi Kulturális Örökség Igazgatósága. Szentendre, 23 p.

Csizi, I. \& Molnár, Zs. (2015): Természetkimélő gazdálkodás szikesen. - MTKH, MTA ÖK, Csákvár - Vácrátót, 92 p.

Csonka-Takács, E. (2010): The Convention the Safeguarding of the Intangible Cultural Heritage in Service of our Living and Surviving Tradition. Task and Opportunities in Hungary. - In Mihály Hoppál (szerk.): Sustainable Heritage. Symposium on European Intangible Cultural Heritage. Budapest: European Folklore Institute, pp. 45-50.

Drew, J. A. \& Henne, A. P. (2006): Conservation biology and traditional ecological knowledge: integrating academic disciplines for better conservation practice. - Ecol. Soc. 11: 34. (Letölthetö: http://www.ecologyandsociety.org/vol11/iss2/art34/)

Eperjessy, E. (2006): Puszták népe a Zselicben. - Mikszáth Kiadó, Horpács, 698 p.

Fernández-Giménez, M. E. \& Estaque, F. F. (2012): Pyrenean pastoralists' ecological knowledge: Documentation and application to natural resource management and adaptation. - Hum. Ecol . 40: 287-300. doi: http://doi.org/10.1007/s10745-012-9463-x

Geiger, B., Saláta, D. \& Malatinszky, Á. (2011): Tájtörténeti vizsgálatok a kisgombosi fás legelőn. - Tájökológiai Lapok 9: 219-233.

Glasenapp, M. \& Thornton, T. F. (2011): Traditional ecological knowledge of Swiss Alpine farmers and their resilience to socioecological change. - Hum. Ecol. 39: 769-781. doi: http://doi. org/10.1007/s10745-011-9427-6

Gugić, G. (2009): Managing Sustainability in Conditions of Change and Unpredictability. The Living Landscape and Floodplain Ecosystem of the Central Sava River Basin. - Lonjsko Polje Nature Park Public Service, Krapje, Croatia, 111 p. 
Halász, A., Tasi, J. \& Rásó, J. (2015): Fás legelők, legelőerdők, erdősávok és fasorok használata ökológiai gazdálkodási rendszerben. - Növénytermelés 64: 77-8.

Harmos, K. (2013): Eltünt fás legelők nyomában. - Zöld Horizont 8: 4-5.

Hartel, T., Plieninger, T. \& Varga, A. (2015): Wood-pastures in Europe. - In: Kirby, K., Watkins, C. (szerk.): Europe's Changing Woods and Forests: From Wildwood to Managed Landscapes. CAB International, pp. 61-76.

Hartel, T. \& Plieninger, T. (2014): European wood-pastures in transition: A social-ecological approach. - London and New York: Routledge. 303 p.

Hartel, T., Dorresteijn, I., Klein, C., Máthé, O., Moga, C. I., Öllerer, K., Roellig, M., Wehrden, H. $\&$ Fischer, J. (2013): Wood-pastures in a traditional rural region of Eastern Europe: Characteristics, 166, management and status. - Biol. Conserv. 166: 267-275. doi: http://doi.org/10.1016/j. biocon.2013.06.020

Johann, E., Agnoletti, M., Bölöni, J., Erol, S. C., Holl, K., Kusmin, J., Latorre, J. G., Latorre, J. G., Molnár, Zs., Rochel, X., Rotherham, I. D., Saratsi, E., Smith, M., Tarang, L., Benthem, M. \& Laar, J., (2012): Europe. - In: Parrotta, J. A. \& Trosper, R. L. (eds.): Traditional Forest-Related Knowledge: Sustaining Communities, Ecosystems and Biocultural Diversity, World Forests 12. Springer Science + Business Media B.V., pp. 203-249.

Kis, J., Barta, S., Elekes, L., Engi, L., Fegyver, T., Kecskeméti, J., Lajkó L. \& Szabó, J. (2016): A pásztorok tudásának és világnézetének szerepe a biodiverzitás és az ökoszisztéma-szolgáltatások fenntartásában. - Természetvédelmi Közlem. 22: 96-111. doi: http://doi.org/10.20332/tvk-jnatconserv.2016.22.96

Luby, M. (1942): Fogyó legelökön. - Anthaeum Kiadás, 228 p.

Meilleur, B. A. (2010): The structure and role of folk ecological knowledge in Les Allues (Savoie), France, - In: Johnson L. \& Hunn E. (eds.): Landscape Ethnoecology: Concepts of Biotic and Physical Space. - Berghahn Books, Oxford and New York, pp. 244-264.

Mihók, B., Kiss, G., Kovács, E., Margóczi, K., Fabók, V. \& Kalóczkai, Á. (2016): Ki mondja meg, mi a fontos? - Részvétel és természetvédelem. - Természetvédelmi Közlem. 22: 131-154. doi: http://doi.org/10.20332/tvk-jnatconserv.2016.22.131

Molnár, K. \& Molnár, Zs. (szerk.) (2015): Sztánai Füzetek 19. - Etnoökológiai kutatótábor Kalotaszegen. Mủvelődés Egyesület - Szentimrei Alapítvány, Kolozsvár-Sztána, 240 p.

Molnár, Zs. (2011a): A hortobágyi pásztorok növényzetismerete. - Botanikai Közlem. 98: 133-172.

Molnár, Zs. (2011b): Hortobágyi pásztorok hagyományos ökológiai tudása a legeltetésröl, kaszálásról és ennek természetvédelmi vonatkozásai. - Természetvédelmi Közlem. 17: 12-30.

Molnár, Zs. (2012): A Hortobágyi pásztorok növényosztályozása, a vadon termő növények ismertsége és néven nevezettsége. - Crisicum 7: 153-207.

Molnár, Zs., Bartha, S. \& Babai, D. (2009): A népi növényzetismeret (etnobotanika) és az etnoökológiai, ökológiai antropológiai megközelítés szerepe napjaink vegetáció- és tájkutatásában. - Botanikai Közlem. 96: 95-116.

Molnár, Zs., Gellény, K., Margóczi, K. \& Biró, M. (2015): Landscape ethnoecological knowledge base and management of ecosystem services in a Székely-Hungarian pre capitalistic village system (Transylvania, Romania).- J. Ethnobiol. Ethnomed. 11: 3. doi: http://doi.org/10.1186/17464269-11-3

Molnár, Zs., Kis, J., Vadász, Cs., Papp, L., Sándor, I., Béres, S., Sinka, G. \& Varga A. (2016): Common and conflicting objectives and practices of herders and conservation managers: the need for a conservation herder - Ecosyst. Health Sustain. 2:16. doi: http://doi.org/10.1002/ehs2.1215

Oellerer, K. (2014): The ground vegetation management of wood-pastures in Romania-Insights in the past for conservation management in the future. - Appl. Ecol. Env. Res. 12: 549-562. 
Oteros-Rozas, E., Ontillera-Sánchez, R., Sanosa, P., Gómez-Baggethun, E., Reyes-García, V. \& González, J. A. (2013): Traditional ecological knowledge among transhumant pastoralists in Mediterranean Spain. - Ecol. Soc. 18: 33. doi: http://dx.doi.org/10.5751/ES-05597-180333

Parrotta, J. A., Agnoletti, M. \& Johann, E. (szerk.). (2006): Cultural heritage and sustainable forest management: The role of traditional knowledge. - Proceedings of the conference, 8-11 June 2006, Florence, Italy. Ministerial Conference on the Protection of Forests in Europe. Liaison Unit Warsaw.

Petercsák, T. (1983): Népi szarvasmarhatartás a zempléni Hegyközben. - Borsodi Kismonográfiák 17., Miskolc, $161 \mathrm{p}$.

Rackham, O. (1998): Savannah in Europe. - In: Kirby, K. J. \& Watkins C. (szerk.): The Ecological History of European Forests. - CAB International, New York, pp. 1-24.

Redecker, B., Härdtle, W., Finck, P., Riecken, U. \& Schröder, E. (szerk.) (2002): Pasture landscape and nature conservation. - Springer, $435 \mathrm{p}$.

Rotherham, I. D. (2015): Bio-cultural heritage and biodiversity: emerging paradigms in conservation and planning. - Biodivers Conserv. 24: 3405-3429. doi: http://doi.org/10.1007/s10531-015$\underline{1006-5}$

Rotherham, I. (2007): The implications of perceptions and cultural knowledge loss for the management of wooded landscapes: A UK case-study. - Forest Ecol. Manag. 249: 100-115. doi: http:// doi.org/10.1016/j.foreco.2007.05.030

Roturier, S. (2011): Sami herders' classification system of reindeer winter pastures - A contribution to adapt forest management to reindeer herding in northern Sweden. - Rangifer 31: 61-69. doi: http://dx.doi.org/10.7557/2.31.1.2020

Roturier, S. \& Roué, M. (2009): Of forest, snow and lichen: Sámi reindeer herders' knowledge of winter pastures in northern Sweden. - Forest Ecol. Manag. 258: 1960-1967. doi: http://doi. org/10.1016/j.foreco.2009.07.045

Saláta, D. (2009): Legelőerdők egykor és ma, A fás legelők és legelőerdők kialakulásának és hasznosításának emlékei egy öreg-bakonyi (Pénzesgyőr-Hárskúti) fás legelő tájtörténeti feltárásnak példáján keresztül, - Erdészettörténeti Közlem. 79. OEE, Budapest, 80 p.

Samu, Z. T., Bódis, J. \& Varga, A. (2015): Egy belső-somogyi fás legelő múltja, jelene és jövője természetvédelmi szempontból. - Természetvédelmi Közlem. 21: 253-261.

Schmeller, D. S. \& Bridgewater, P. (2016): The Intergovernmental Platform on Biodiversity and Ecosystem Services (IPBES): progress and next steps. - Biodivers. Conserv. 25: 801-805. doi: http://doi.org/10.1007/s10531-016-1095-9

Stiven, R. (2009): Management of ancient wood pastures. - Forestry Commission Scotland, 14 p.

Szigetvári, Cs. (2015): Legeltetés, gyepre alapozott állattartás természetvédelmi szempontú értékelése. - E-misszió Természet- és Környezetvédelmi Egyesület. Nyíregyháza, 100 p.

Takáts, Gy. (1986): Somogyi pásztorvilág. - Somogy Megyei Múzeumok Igazgatósága, Kaposvár, $124 \mathrm{p}$.

Varga, A. \& Bölöni, J. (2009): Erdei legeltetés, fáslegelők, legelőerdők tájtörténeti kutatása. - Természetvédelmi Közlem. 15: 68-79.

Varga A. \& Molnár Zs. (2013): Ehető vadgyümölcsök és gombák gyüjtése egy bakonyi fás legelőn. - Dunántúli Dolgozatok. Természettudományi Sorozat 13: 93-102.

Varga, A. \& Molnár, Zs. (2014): The Role of Traditional Ecological Knowledge in Managing Woodpastures. - In: Hartel, T. \& Plininger, T. (szerk.): European Wood-pastures in Transition. - London and New York: Routledge, pp. 187-202.

Varga, A., Ódor, P., Molnár Zs. \& Bölöni János (2015): The history and natural regeneration of a secondary oak-beech woodland on a former wood-pasture in Hungary - Acta Soc. Bot. Pol. 84: 215-225. doi: http://doi.org/10.5586/asbp.2015.005 
Varga, A., Heim, A., Demeter, L. \& Molnár, Zs. (2017): Rangers bridge the gap: Integration of traditional ecological knowledge related to wood pastures into nature conservation - In: Roué , M. \& Molnar Zs. (szerk.): Knowing our Land and Resources: Indigenous and local knowledge of biodiversity and ecosystem services in Europe \& Central Asia. - Knowledges of Nature 9. UNESCO: Paris, pp. 7689.

Varga, A., Molnár, Zs., Biró, M., Demeter, L., Gellény, K., Miókovics, E., Molnár, Á., Molnár, K., Ujházy, N., Ulicsni, V. \& Babai, D. (2016): Changing year-round habitat use of extensively grazing cattle, sheep and pigs in East-Central Europe between 1940 and 2014: Consequences for conservation and policy. - Agr. Ecosyst. Environ. 234 :142-153. doi: http://doi.org/10.1016/j. agee.2016.05.018

Varga, A., Saláta, D., Zlinszky, A., Samu, Z., Biró, M., Vityi, A., Moreno, G. \& Molnár, Zs. (2017): From farm scale to country scale: investigation of the high nature and cultural value wood pastures in Hungary, Central Europe. - Vácrátót, MTA ÖK, Kézirat.

\title{
Traditional wood pasture management based on herders and farmers knowledge in Hungary
}

\author{
Anna Varga ${ }^{1}$, Zoltán Tamás Samu² and Zsolt Molnár ${ }^{1}$ \\ ${ }^{1}$ MTA Center for Ecological Research Institute of Ecology and Botany, \\ H-2163 Vácrátót, Alkotmány u. 2-4, Hungary \\ ${ }^{2}$ Balaton Museum, \\ H-8630 Keszthely, Múzeum u. 2, Hungary \\ email: varga.anna@gmail.com
}

The traditional ecological knowledge is an essential part of the biocultural heritage. This knowledge is indispensable for nature conservation of many habitat types. One of those habitats is the wood pastures, which is part of the agroforestry systems. For the last couple of years the interest for the wood pasture management has been growing from the side of conservation and the agricultural experts as well. Our aim was to synthesize the living traditional ecological knowledge of wood pastures in Hungary. During our research we conducted semi-structured interviews with 52 herders and farmers at 28 locations around Hungary. In many cases wood pasture management is based on living traditional ecological knowledge. Herders and farmers shared their deep knowledge about the vegetation dynamics of the wooded vegetation and the sustainable grazing management as well. It is important to highlight that the number of traditional herders are decreasing, but there are nature conservation managers, rangers and couple of young herders and farmers who could pass this knowledge to the future generations. The use of traditional ecological knowledge of the wood pastures could improve the efficiency of nature conservation, conserve cultural heritage and strengthen the herders' community as well.

Keywords: traditional ecological knowledge, agroforestry systems, nature conservation management, land use, intangible cultural heritage 